\title{
EFFECTS IN MAN OF ACUTE EXPERIMENTAL RESPIRATORY ALKALOSIS AND ACIDOSIS ON IONIC TRANSFERS IN THE TOTAL BODY FLUIDS ${ }^{1}$
}

\author{
By J. R. ELKINTON,² R. B. SINGER, ${ }^{3}$ E. S. BARKER,, ${ }^{4}$ AND J. K. CLARK \\ (From the Chemical Section and Renal Section of the Department of Medicine, the Department \\ of Research Medicine, and the Department of Biochemistry, the University of \\ Pennsylvania School of Medicine, Philadelphia, Pa.)
}

(Submitted for publication January 31, 1955; accepted August 3, 1955) Although the concept of tissue buffering was
formulated early in the study of acid-base dis-
turbances, attention in the past has been directed
primarily towards the effects of these disturbances
on blood and extracellular fluid. More recently the demonstration by Darrow and his co-workers (1-3) of exchanges of intracellular cations during clinical and experimental potassium deficiency stimulated renewed interest in the quantitative aspects of the buffering action of intracellular fluid. Accordingly, some years ago the authors undertook quantitative estimation of the effects in man of acute experimental respiratory alkalosis and acidosis on the components of the multiphase system of red cells, plasma, interstitial fluid, and "intracellular" fluid (calculated as the non-chloride space), as well as on exchanges in the kidney. The latter renal effects will be reported in another paper (4).

Our results indicate that in man the effects of acute hyperventilation or carbon dioxide inhalation are buffered to a large extent by a series of linked ionic exchanges with a phase or phases outside the chloride space, as well as with buffer systems within the blood and extracellular fluid. Since these findings were reported in abstract (5-8) similar conclusions have been reached by Giebisch, Berger, and Pitts (9), on the basis of experimental respiratory disturbances in the dog. Estimates of the importance of tissue buffering

\footnotetext{
${ }^{1}$ Laboratory facilities were aided by grants from the Life Insurance Medical Research Fund, the National Heart Institute of the United States Public Health Service (Grants H-340 and H-405), and the C. Mahlon Kline Fund for Development in the Department of Medicine.

2 Established Investigator of the American Heart Association.

3 Present address : 501 Boylston Street, Boston, Mass.

${ }^{4}$ During tenure of Post-doctorate Fellowship of the National Institutes of Health, United States Public Health Service.
}

have also been made in acute metabolic alkalosis and acidosis in man $(10,11)$ and in the dog (1214).

\section{EXPERIMENTAL PROCEDURE AND METHODS}

The effects of the two opposite types of respiratory disturbance, hyperventilation and $\mathrm{CO}_{2}$ inhalation, were assessed by comparison of the changes observed from the control period to the period during altered respiration and from the latter to the recovery period. This assessment has been made by use of the balance technic; the method of calculation is presented in the next section.

Twelve normal men between the ages of 19 and 34, students and physicians, served as experimental subjects. All subjects were in the fasting state and the studies were performed during the morning hours (8 A.M. to 12 noon); during this interval diurnal variations in acidbase balance and renal function should be small, unidirectional, and comparable between all experiments as a control background. Standard loading of the subjects with water and solutes was carried out before and during the experiments as follows. In the respiratory alkalosis experiments, this consisted essentially in water loading only in amounts equivalent to urine excreted. In the respiratory acidosis experiments, Experiments 1 to 5 inclusive, the subjects were given $4.2 \mathrm{gm} . \mathrm{NaHCO}_{3}$ ( $50 \mathrm{mEq}$.) by mouth at -95 to -150 minutes to produce a very slight metabolic alkalosis and ensure a neutral or alkaline urine before the onset of the stimulus; in the sixth experiment $\mathrm{NaCl}$ was given as a control. In all. the latter experiments one liter of water was given with the salt as a priming solution to institute an adequate and relatively constant urine flow; subsequently water was taken orally in amounts equivalent to urinary excretion. All subjects remained recumbent throughout the experiments.

Following control periods of 47 to 74 minutes' duration, respiratory alkalosis was induced by voluntary hyperventilation for approximately 30 minutes in 5 of the 6 experiments, and for twice that period in the last experiment; respiratory acidosis was induced by breathing 7.5 to 7.7 per cent $\mathrm{CO}_{2}$ in air or $\mathrm{O}_{2}$ for periods of 21 to 30 minutes. Observations were continued during recovery periods of 67 to 110 minutes in duration. During both sets of experiments serial measurements of the acidbase factors of blood and of the concentration of elec- 
trolytes in plasma were made on samples of arterial or cutaneous arterialized blood $(15,16)$. In a few instances ions other than bicarbonate were measured in venous serum. Simultaneously measurements were made of the renal clearance of electrolytes and of renal hemodynamics, to be described in a subsequent paper (4).

Heparinized blood for acid-base studies was collected and handled with precautions to prevent loss of $\mathrm{CO}_{2}$ $(10,16)$. One portion of each sample was centrifuged anaerobically, and the plasma drawn off and stored in a greased syringe for analysis of total $\mathrm{CO}_{2}$ by means of the manometric Van Slyke and Sendroy apparatus (17), sodium and potassium with a Barclay internal standard flame photometer (18), and chloride by a titrimetric silver iodate method (19). The remaining portion of each sample of blood was stored in the capped syringe in an ice bath until aliquots were taken for determination of hemoglobin (20), and of hematocrit value, $\mathrm{pH}$ and whole blood $\mathrm{CO}_{2}$ by a modification of the Shock and Hastings microtechnique $(21,16)$. In this modification visual colorimetric comparison of $\mathrm{pH}$ at $37^{\circ} \mathrm{C}$. was replaced by reading in the Klett-Summerson photometer, with a green filter, in a manner similar to that described by Van Slyke, Weisiger, and Van Slyke (22). The standard error of this measurement was $\pm 0.009 \mathrm{pH}$ unit for a single reading; these measurements, however, were always made in triplicate. Venous blood, when used, was allowed to clot, was centrifuged under oil, and the serum was drawn off for analysis of sodium, potassium, and chloride. By use of the Singer-Hastings nomogram (15) and the Henderson-Hasselbalch equation, ${ }^{5}$ values were derived (from the observed values of plasma $\mathrm{pH}$ as measured in whole blood and from $\mathrm{CO}_{2}$ content of plasma) for three additional values: arterial $\mathrm{CO}_{2}$ pressure, plasma bicarbonate concentration, and concentration of buffer base. Buffer base represents the cation equivalent of the sum of bicarbonate and all other buffer anions.

\section{CALCULATIONS}

General principles. Transfers of sodium and potassium often have been estimated in respect to calculated changes in "extracellular" fluid as equated with the chloride space $(1,24)$. In essentially the same manner it is possible to calculate from the changes in total "extracellular" bicarbonate the transfers of hydrogen ion into and out of the chloride space, when allowance has been made for the uptake or release of hydrogen ion by the nonbicarbonate buffers in red cells and plasma, and for the excretion of hydrogen by the kidney. The method of calculation employed here is similar to that described

${ }^{5}$ From the Henderson-Hasselbalch equation:

where

$$
\mathrm{pH}=\mathrm{pK}_{1}{ }^{\prime}+\log \frac{\left(\mathrm{HCO}_{3}^{-}\right)}{\mathrm{fP}_{\mathrm{CO}_{2}}}
$$

$\mathrm{pK}_{1}^{\prime}=6.10$ at $37^{\circ} \mathrm{C}$. (23)

$\mathrm{f}=0.0314 \mathrm{mM}$ per liter per $\mathrm{mm} . \mathrm{P}_{\mathrm{CO}_{2}}$ at $37^{\circ} \mathrm{C}$. in plasma or serum with an average water content of $938 \mathrm{~g}$. per liter (23). previously (10), but allowance is also made in the present report for shifts of chloride between red cells and plasma. This is necessary since under these experimental circumstances such shifts may make a significant difference in calculated fluid volumes. These calculations require values for initial and final "extracellular" fluid volumes. Such an initial volume was assumed and the final volume was calculated by correction according to change in serum concentration and external balance of chloride. This is probably at least as accurate for our purpose as direct measurement by substances such as inulin or radio-sulfate since the changes in this chloride space and in the associated cationic transfers are relatively little affected by variations in the initial absolute "extracellular" volume. The validity of the use of the chloride space is taken up under Discussion.

Transfers of hydrogen ion into and out of the chloride space, the red cells being included with this "extracellular fluid," may be calculated from changes in the total amount of reacting buffer anions. Hydrogen ion can combine with bicarbonate or non-bicarbonate buffers (Buf-), chiefly hemoglobin and plasma protein anions in blood, in the following manner:

$$
\begin{aligned}
\mathrm{H}^{+}+\mathrm{HCO}_{3}^{-} & \rightleftharpoons \mathrm{H}_{2} \mathrm{CO}_{3} \rightleftharpoons \mathrm{H}_{2} \mathrm{O}+\mathrm{CO}_{2} \\
\mathrm{H}^{+}+\mathrm{Buf}^{-} & \rightleftharpoons \mathrm{HBuf}
\end{aligned}
$$

The $\mathrm{CO}_{2}$ is volatile, $\mathrm{HBuf}$ is non-volatile. In metabolic acidosis the influx of strong acid provides hydrogen ion which must be buffered by decrease of both bicarbonate and other buffer anions as shown in Equations 1 and 2. The excess $\mathrm{H}^{+}$which reacts with dissociated buffer anions, Buf-, produces an equivalent rise in the undissociated acid, $\mathrm{HBuf}$, and this excess $\mathrm{H}^{+}$can be identified as remaining in the chloride space in the form of a nonionized acid. On the other hand, the excess $\mathrm{H}^{+}$reacting with $\mathrm{HCO}_{3}^{-}$ordinarily cannot be so identified, since the non-metabolic carbonic acid formed is broken down into water and carbon dioxide which is very promptly eliminated through the lungs. The excess $\mathrm{H}^{+}$therefore is accountable as a measured or calculated decrease in the sum of the buffer anions, or in their cationic equivalent, the buffer base, $\mathrm{BB}^{+}$. In primary respiratory disturbances the respective changes in $\mathrm{HCO}_{3}{ }^{-}$and $\mathrm{Buf}^{-}$are in opposite directions, instead of in the same direction. When whole blood is saturated in vitro with air- $\mathrm{CO}_{2}$ mixtures each increase or decrease in $\mathrm{HCO}_{3}^{-}$is balanced by an equal and opposite change in Buf ${ }^{-}$. The reactions represented in Equations 1 and 2 are reciprocal reactions, and the buffer base content of whole blood is constant, although the chloride shift results in a limited redistribution of the buffer base between plasma and red cells.

The situation is more complicated when such changes are considered in vivo, with at least four phases to be accounted for simultaneously. These include red cells, plasma, interstitial fluid, and "intracellular" fluid. In addition, effects of renal excretion must be considered. By means of appropriate measurements all of these factors can be calculated in such a way as to yield a quantity designated the "intracellular" hydrogen change, $\Delta \mathrm{H}_{1}{ }^{+}$. 
This value represents hydrogen ion that must be accounted for in respect to a change in the total quantity of "extracellular" plus red cell buffer base, $\Delta \mathrm{BB}_{\mathrm{er}}{ }^{+}$, corrected for the external non-respiratory balance of hydrogen ion, $\mathrm{b}_{\mathbf{H}}{ }^{+}$. It is calculated as follows :

$$
\Delta \mathrm{H}_{\mathrm{i}}{ }^{+}=\Delta \mathrm{BB}_{\mathrm{er}}{ }^{+}-\mathrm{b}_{\mathrm{H}^{+}} \text {. }
$$

Although this is designated as hydrogen moving in one direction, it may also represent bicarbonate moving in the opposite direction across the phase boundary; the two cannot be differentiated. If $\Delta \mathrm{H}_{1}{ }^{+}$is positive, one may refer to a transfer of hydrogen ion into the cells, and if negative, out of the cells. It should be understood, however, that these opposite changes may represent only a change in the rate of movement of the ion in a constant direction rather than reversal of its movement. The continuing metabolism present in the dynamic equilibrium which we designate as a "steady state" provides acid products which cause a steady movement of hydrogen ions out of the intracellular fluid. In response to respiratory acidosis one may calculate a positive $\Delta \mathrm{H}_{1}{ }^{+}$, and describe it as a shift of hydrogen ion into cells. It may represent, however, a decrease in the steady rate at which the ion is moving out of cells, a process that would have an identical effect on the intracellular and extracellular fluid.

The method of calculation of $\Delta \mathrm{BB}_{\mathrm{er}}{ }^{+}$was similar to that described previously $(10)$, with certain modifications occasioned by the fact that the chloride shift cannot be neglected in respect to these ionic transfers. The altered quantity of buffer base was derived from

$$
\Delta \mathrm{BB}_{\mathrm{er}}{ }^{+}=\Delta \mathrm{HCO}_{3 \mathrm{er}}{ }^{-}+\Delta \mathrm{Buf}_{\mathrm{b}}{ }^{-},
$$

where $\Delta \mathrm{Buf}_{\mathrm{b}}{ }^{-}$is the change in non-bicarbonate blood buffer anions as calculated below in Equation 9, and $\Delta \mathrm{HCO}_{\mathrm{e}_{\mathrm{er}}}{ }^{-}$is the change in total "extracellular" plus red cell bicarbonate calculated as follows:

$$
\Delta \mathrm{HCO}_{3 \mathrm{er}}^{-}=\Delta \mathrm{HCO}_{3 \mathrm{p}^{-}}+\Delta \mathrm{HCO}_{3 \mathrm{f}}^{-}+\Delta \mathrm{HCO}_{3 \mathbf{r}^{-}} \text {. }
$$

For plasma, interstitial fluid and red cells, indicated by subscripts $p, f$ and $r$, respectively, the change in the amount of bicarbonate between observation 1 and 2 is given by the equation:

$$
\Delta \mathrm{HCO}_{3}^{-}=\mathrm{V}_{2}\left(\mathrm{HCO}_{3}^{-}\right)_{2}-\mathrm{V}_{1}\left(\mathrm{HCO}_{3}^{-}\right)_{1},
$$

where $\mathrm{V}_{1}$ and $\mathrm{V}_{2}$ represent initial and final volumes, respectively. The bicarbonate concentration in plasma, $\left(\mathrm{HCO}_{3}^{-}\right)_{\mathrm{p}}$, was calculated from the observed plasma total $\mathrm{CO}_{2}$ concentration and $\mathrm{pH}$, by means of the Henderson-Hasselbalch equation. Red cell "bicarbonate" (including carbamino $\mathrm{CO}_{2}$ ) was calculated from the whole blood total $\mathrm{CO}_{2}$, plasma total $\mathrm{CO}_{2}$ and red cell volume, the appropriate subtraction being made for carbonic acid on the basis of the solubility coefficient and $\mathrm{CO}_{2}$ pressure. The whole blood $\mathrm{CO}_{2}$ concentration was calculated from the plasma $\mathrm{CO}_{2}$ concentration, $\mathrm{pH}$, and whole blood hemoglobin concentration by means of the line chart of Van Slyke and Sendroy (17), on the assumption of complete oxygen saturation in the arterial or cutaneous blood. In the experiments where cutaneous blood samples were used the plasma $\mathrm{CO}_{2}$ concentration was calculated from whole blood $\mathrm{CO}_{2}$. Interstitial fluid bicarbonate concentration, $\left(\mathrm{HCO}_{3}^{-}\right)_{\mathrm{f}}$, was derived from $\left(\mathrm{HCO}_{3}^{-}\right)_{\mathbf{p}}$ by the following equation:

$$
\left(\mathrm{HCO}_{3}{ }^{-}\right)_{\mathrm{f}}=1.16\left(\mathrm{HCO}_{3}{ }^{-}\right)_{\mathrm{p}} \text {. }
$$

The factor 1.16 is based on a Donnan ratio of arterial plasma to interstitial fluid bicarbonate concentration, expressed per kilogram of water, of 0.91 , and a water content of 935 grams per liter in plasma and 990 grams per liter in interstitial fluid (25). The rather low value of this Donnan ratio as compared with the usually quoted one of 0.95 or 0.96 is explained by the relatively large arterio-venous difference for bicarbonate. The corresponding factors which were used for the concentrations of $\mathrm{Cl}, \mathrm{Na}$ and $\mathrm{K}$ were as follows: $1.08,1.015$, and 0.97 , respectively $(26,27)$.

Initial control values of blood volume, $\mathrm{V}_{\mathrm{b}}$, and extracellular fluid volume, $\mathrm{V}_{\mathrm{e}}$, were assumed, $80 \mathrm{ml}$. per $\mathrm{Kg}$. body weight for the former $(28,29)$ and $200 \mathrm{ml}$. per $\mathrm{Kg}$. body weight for the latter (10). Successive values of blood volume were calculated from hemoglobin concentrations, $(\mathrm{Hb})$, by the equation:

$$
\mathrm{V}_{\mathrm{b}_{2}}=\mathrm{V}_{\mathrm{b}_{1}} \frac{(\mathrm{Hb})_{1}}{(\mathrm{Hb})_{2}} \text {. }
$$

For each blood volume the corresponding plasma and red cell volumes, $V_{p}$ and $V_{r}$, were derived with the aid of the observed hematocrit value. The initial interstitial fluid volume was obtained as the difference between the initial assumed extracellular and plasma volumes. Subsequent values of interstitial fluid volume, $V_{\boldsymbol{f}}$, were calculated in terms of the chloride content of blood and interstitial fluid, allowance being made for loss of chloride in the urine and shifts between blood and interstitial fluid; the assumption was made that there was an equilibrium in chloride concentration between blood and interstitial fluid at the time of sampling. Where whole blood chloride was not measured an initial value was calculated and transfers between plasma and red cells were taken in accordance with the $\mathrm{pH}$ changes and the average transfer per unit change in $\mathrm{pH}$ observed in the arterial blood experiments. For each observation after the initial one it was thus possible to calculate (a) the amount of chloride in interstitial fluid, on the assumption that no exchange occurs with tissue cells, (b) the interstitial fluid chloride concentration, $\left(\mathrm{Cl}^{-}\right)_{\mathrm{r}}$, as $1.08 \times\left(\mathrm{Cl}^{-}\right)_{\mathrm{p}}$, and (c) the interstitial fluid volume as the quotient of amount divided by concentration. These volumes were used to calculate not only the bicarbonate distribution, but also the distribution of extracellular sodium and potassium.

The final term in Equation 4, the change in non-bicarbonate blood buffer anions, was calculated from the observed $\mathrm{pH}$ changes, hemoglobin concentration, and assumed blood volume as follows :

$$
\Delta \mathrm{Buf}_{\mathrm{b}}{ }^{-}=\left[7.0 \mathrm{~V}_{\mathrm{p}}+2.3(\mathrm{Hb})_{\mathrm{b}} \mathrm{V}_{\mathrm{b}}\right] \Delta \mathrm{pH} .
$$

The hemoglobin concentration is here expressed in $\mathrm{mM}$ per $\mathrm{L}$. and $\mathrm{pH}$ in units of $1=0.01$. This equation is based 
on buffer data for normal human blood of Dill, Edwards, and Consolazio (23), as adapted in a slightly different form (15).

With the value for $\Delta \mathrm{BB}_{\mathrm{er}}{ }^{+}$thus obtained, the non-respiratory hydrogen ion balance, $\mathrm{b}_{\mathrm{H}}{ }^{+}$, must be calculated in order to solve Equation 3 for change in intracellular hydrogen ion. In the absence of intake this hydrogen ion balance is calculated from the urinary excretion of ammonia and titratable acid, $\mathrm{UV}_{\mathrm{NH}_{4}}{ }^{+}$and $\mathrm{UV}_{\mathrm{TA}}$, which measure hydrogen excreted through the kidney, and of bicarbonate, $\mathrm{UV}_{\mathrm{HCO}_{3}}{ }^{-}$, which is equivalent to hydrogen ion added to the body:

$$
\mathrm{b}_{\mathrm{H}^{+}}{ }^{+}=-\left[\left(\mathrm{UV}_{\mathrm{NH}_{4}}{ }^{+}+\mathrm{UV}_{\mathrm{TA}}\right)-\mathrm{UV}_{\mathrm{HCO}_{3}}{ }^{-}\right] \text {. }
$$

Given the values for $\Delta \mathrm{BB}_{\mathrm{er}}^{+}$and for $\mathrm{bu}^{+}$the change in intracellular hydrogen ion, $\Delta \mathrm{H}_{1}{ }^{+}$, is then calculated from Equation 3.

\section{RESULTS}

\section{Effects on blood and plasma}

All results have been evaluated by standard statistical procedures. These results are presented in Tables I A and I B and in Figures 1 and 2.

Acid-base factors of blood and plasma (Figure 1). In response to voluntary hyperventilation the

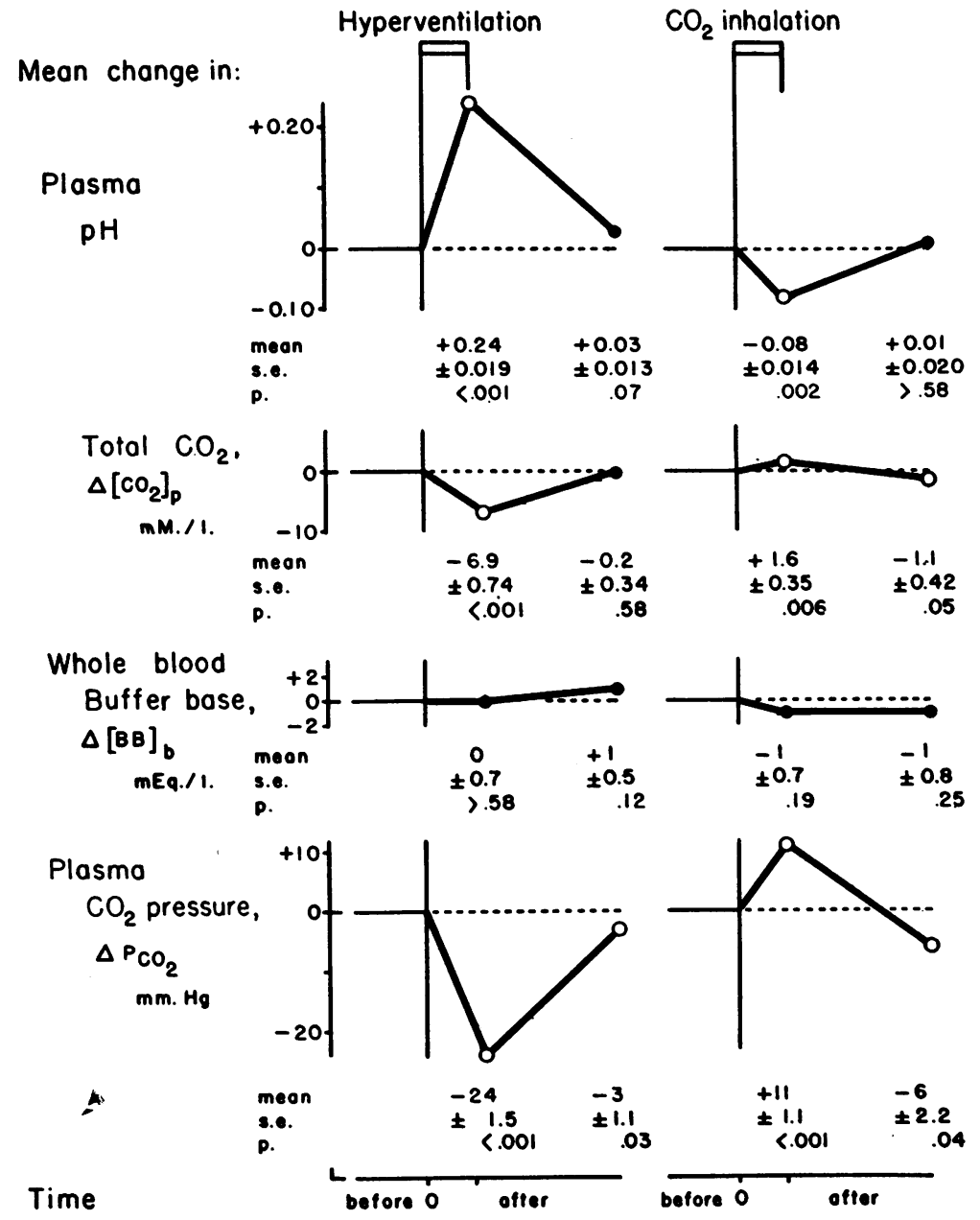

Fig. 1. Acute Respiratory Almalosis and Acidosis: Mean Changes in Plasma pH, Plasma $\mathrm{CO}_{2}$ Content, Whole Bloop Buffer Base Concentration, and $\mathrm{CO}_{2}$ Pressure in Plasma

The mean for each group of changes from the individual mean control values are plotted for the end of the period of stimulus and the end of the recovery period. The values for the mean, its standard error, and the probability that the mean change is significantly different from the control, are given below the curves. The mean changes that are statistically significant are represented by open circles. 


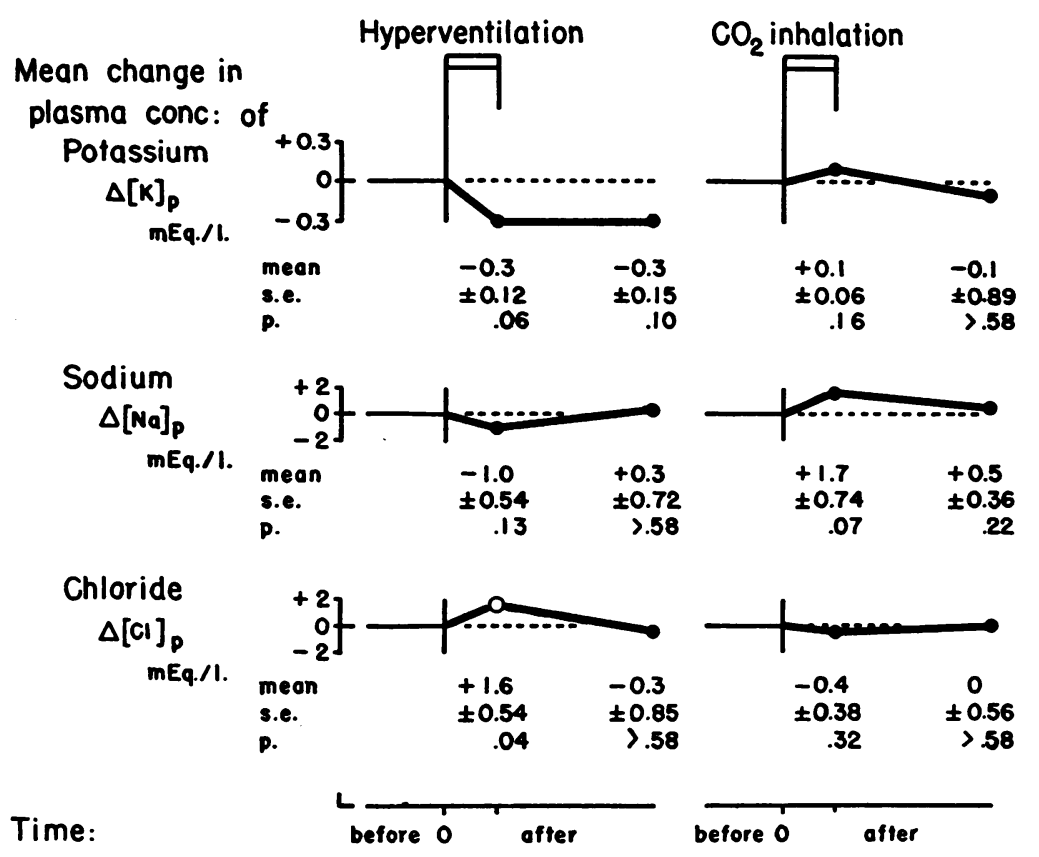

Fig. 2. Acute Respiratory Alkalosis and Acidosis: Mean Changes in the Plasma Concentration of Potassium, Sodium, and Chloride The data are presented as in Figure 1.

$\mathrm{pH}$ rose (mean $=+0.24 \mathrm{pH}$ unit), the $\mathrm{CO}_{2}$ content fell ( $-6.9 \mathrm{mM}$ per L.), the pressure of $\mathrm{CO}_{2}$, $\mathrm{P}_{\mathrm{CO}_{2}}$, fell $(-24 \mathrm{~mm} . \mathrm{Hg})$, and the buffer base concentration, $\left(\mathrm{BB}^{+}\right)_{\mathrm{b}}$, was constant. These changes define a primary respiratory alkalosis or carbonic acid deficit. After the stimulus these values returned to or towards the control levels. In $\mathrm{CO}_{2}$ inhalation the $\mathrm{pH}$ fell $(-0.08 \mathrm{pH}$ unit), the $\mathrm{CO}_{2}$ content rose $(+1.6 \mathrm{mM}$ per L.), the $\mathrm{P}_{\mathrm{CO}_{2}}$ rose $(+11 \mathrm{~mm} . \mathrm{Hg})$, and the buffer base concentration was essentially unchanged $(-1$ $\mathrm{mEq}$. per L. These findings are characteristic of a primary respiratory acidosis or carbonic acid excess. After the inhalation, elevated values for $\mathrm{P}_{\mathrm{CO}_{2}}$ and total $\mathrm{CO}_{2}$ returned to normal, actually overshooting to reach a significantly decreased value at the end of the experiments. Since the mean changes in $\mathrm{pH}$ and $\mathrm{P}_{\mathrm{CO}_{2}}$ were greater during voluntary hyperventilation than during $\mathrm{CO}_{2}$ inhalation, it is apparent that of the two procedures the former was a considerably more severe disturbance and hence, in comparison to $\mathrm{CO}_{2}$ inhalation, evoked more extreme as well as more consistent responses in the body.

Plasma concentration of other electrolytes (Figure 2). Slight changes were obtained in the mean concentrations of sodium, potassium, and chloride. Although in most instances these changes were not statistically significant, they were in opposite directions with the two stimuli and in the direction predictable on theoretical grounds. When converted from concentration changes to changes in total extracellular amounts many of these changes are significant. The decrease in potassium concentration of $-0.3 \mathrm{mEq}$. per $\mathrm{L}$. at the end of hyperventilation (significant at the 6 per cent level but not at the 5 per cent level) is in accord with other observations in experimental respiratory alkalosis $(30,31)$. The significant increase in chloride concentration, $+1.6 \mathrm{mEq}$. per L., occurring in respiratory alkalosis, is predicted on theoretical grounds from the effect of the $\mathrm{pH}$ rise in decreasing the Donnan ratio of red cell chloride to plasma chloride (23).

\section{Calculated effects on ionic transfers in the total body fluids}

These results are presented in Tables II A, II B, III $A$, and III $B$, and in Figures 3 to 6 , inclusive. In Tables II A and II B are presented the observed balance data, the calculated ionic concentrations in 
J. R. ELKINTON, R. B. SINGER, E. S. BARKER, AND J. K. CLARK

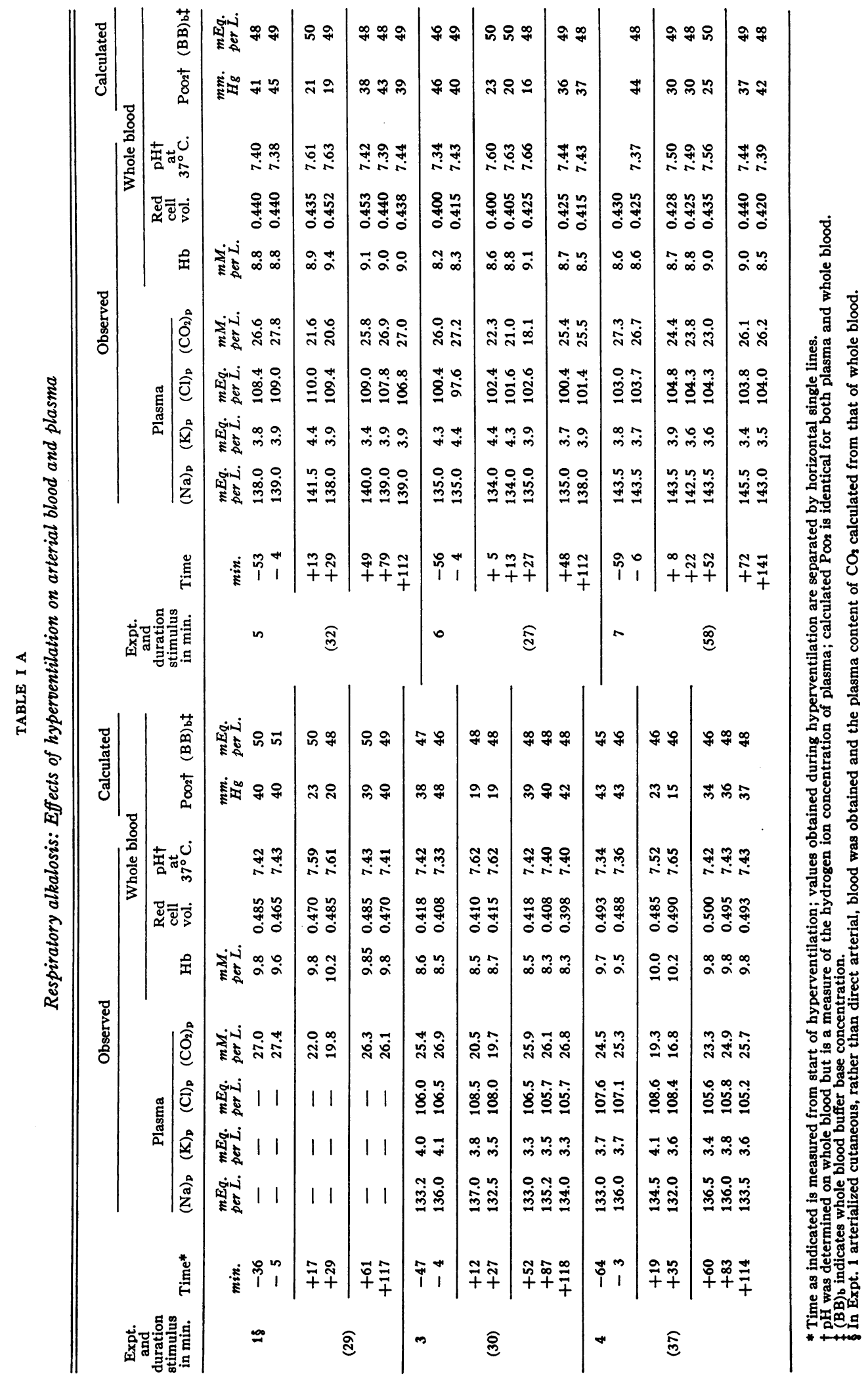


莣

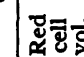

ỡ 运

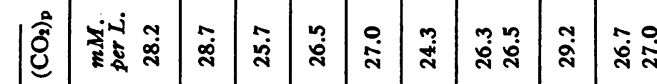

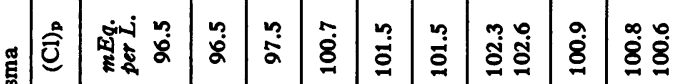

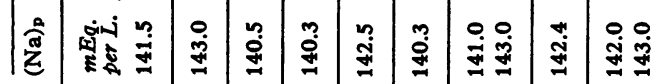

$\underset{\sharp}{\Xi}$

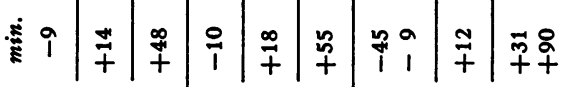

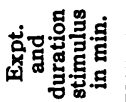

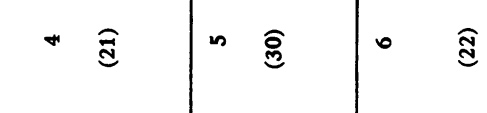


interstitial fluid, and the calculated volumes of the several fluid phases, all of which are necessary to the calculation of the ionic transfers shown in Tables III A and III B.

Extracellular bicarbonate and buffer base, and intracellular hydrogen (Tables III $A$ and III $B$, Figures 3 and 4 ). In respiratory alkalosis, at the end of the stimulus, the total extracellular bicarbonate changed by a mean of $-136 \mathrm{mEq}$. with a reciprocal change in total non-bicarbonate buffer anion of $+39 \mathrm{mEq}$. In respiratory acidosis the same changes were $+32 \mathrm{mEq}$. and $-12 \mathrm{mEq}$., respectively. The algebraic sum of these two values, the change in total extracellular buffer base, was $-97 \mathrm{mEq}$. in respiratory alkalosis and +20 $\mathrm{mEq}$. in respiratory acidosis. All values except the last were significant at the 5 per cent level. However, from the end of the $\mathrm{CO}_{2}$ inhalation to the end of the recovery period a change in the opposite direction occurred with the loss of $36 \mathrm{mEq}$. of extracellular buffer base. This recovery change was highly significant ( $p<0.001$ ), a finding adding strong support to the contention that the initial response during $\mathrm{CO}_{2}$ inhalation was real. When these values are corrected for the small amounts of buffer base excreted with bicarbonate and conserved by the secretion of acid and ammonium by the kidney, they provide a quantitative estimate of the transfer between the extracellular and intracellular phases of hydrogen ion in one direction or bicarbonate in the other (Figure 4). Thus, taken as change in the former, the mean change in intracellular hydrogen was -92 $\mathrm{mEq}$. in respiratory alkalosis and $+22 \mathrm{mEq}$. in respiratory acidosis. Once again, while the mean change in intracellular hydrogen between control periods and the end of the stimulus was significant in the alkalosis group only $(p=0.005)$, the mean reciprocal change from the end of the stimulus to

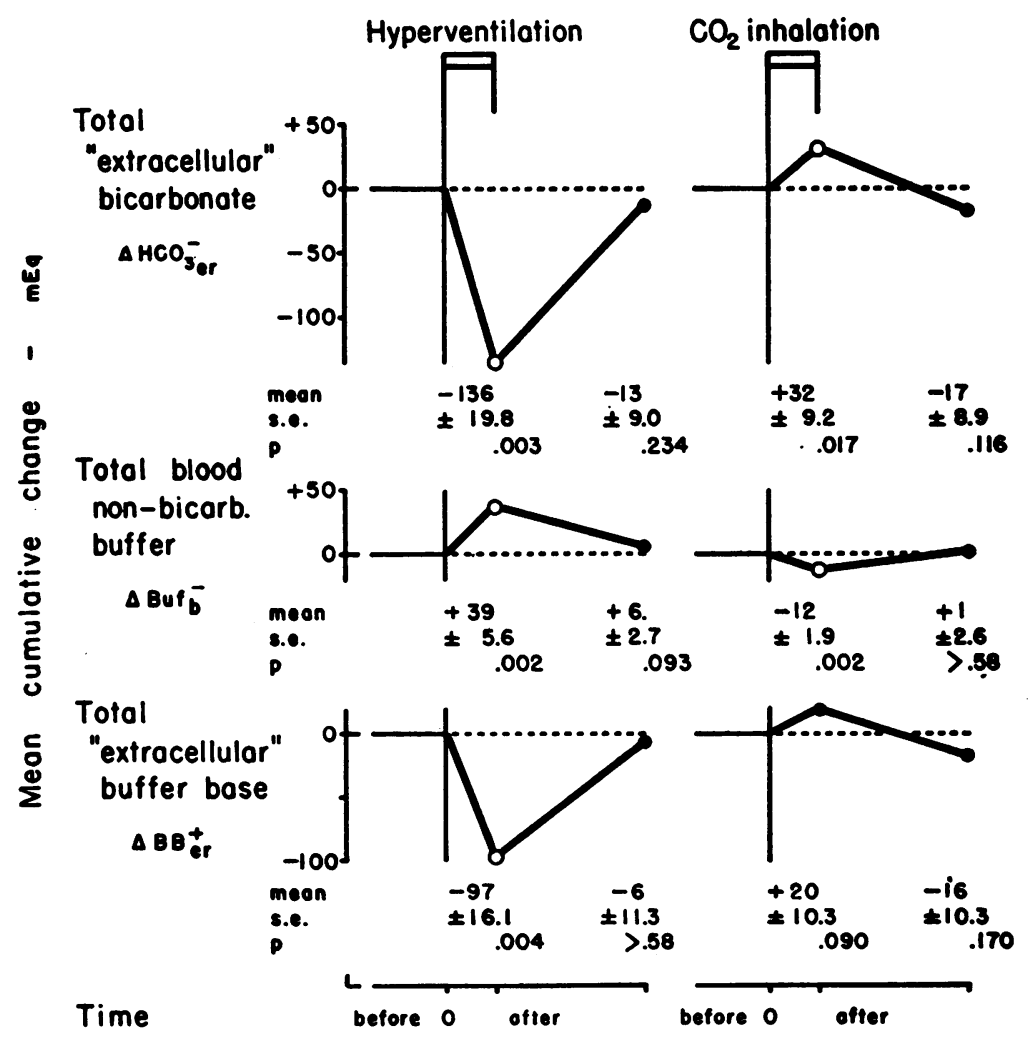

Fig. 3. Acute Respiratory Alkalosis and Acidosis: Mean Changes in Total "Extracellular Bicarbonate," Total Blood Non-Bicarbonate Buffer Anion, and Total "Extracellular" Buffer Base

The data are presented as in Figure 1. 


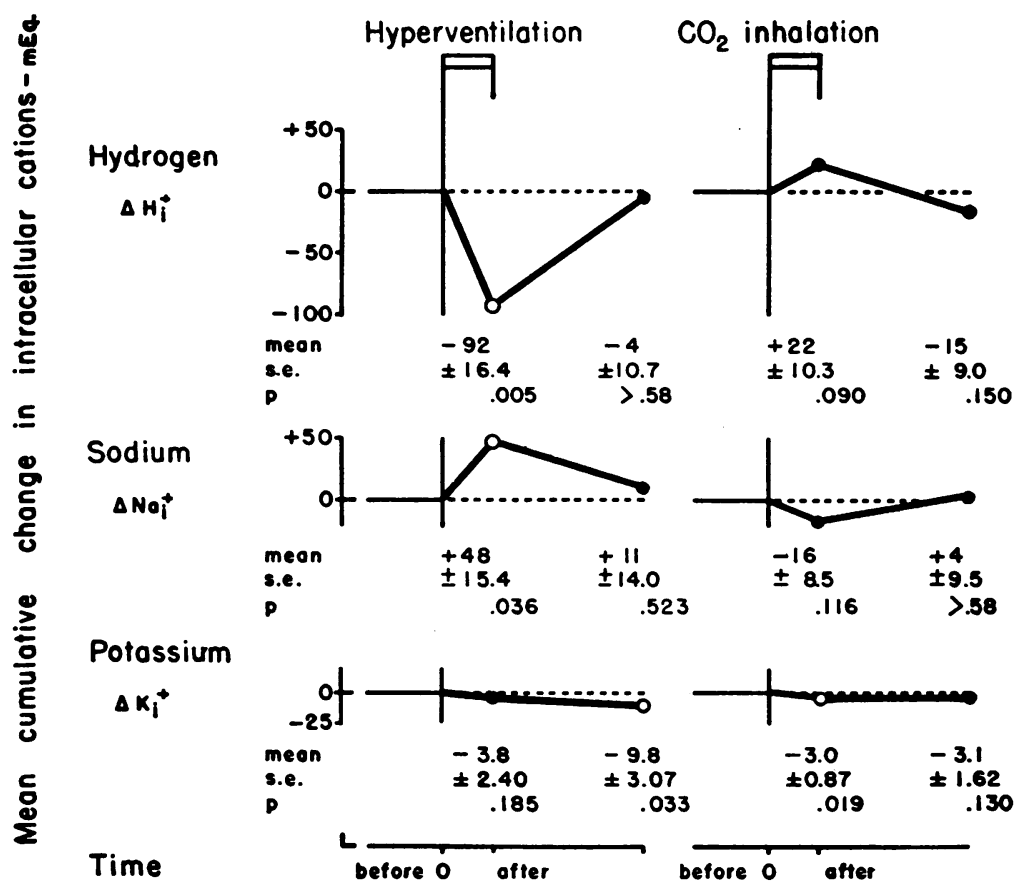

Fig. 4. Acute Respiratory Alkalosis and Acidosis: Mean Changes in Intracellular Hydrogen, Sodium, and Potassium

The data are presented as in Figure 1.

the end of recovery following $\mathrm{CO}_{2}$ inhalation was highly significant ( $-37 \mathrm{mEq} ., \mathrm{p}<0.001)$.

Intracellular sodium and potassium (Tables $I I I A$ and III $B$, Figure 4). In respiratory alkalosis sodium decreased in the chloride space to a far greater extent than it was lost in the urine; in respiratory acidosis sodium increased or was unchanged in this phase. On the assumption that the chloride space is essentially equivalent to the extracellular fluid, these data indicate that sodium moved into the intracellular phase by a mean value of $+48 \mathrm{mEq}$. during respiratory alkalosis; during respiratory acidosis the mean change of -16 $\mathrm{mEq}$. was in the opposite direction but was not statistically significant. During the recovery period in each type of disturbance the intracellular sodium returned to the control levels; the change from the end of the $\mathrm{CO}_{2}$ inhalation to the end of the recovery period being $+20 \mathrm{mEq}$., $\mathrm{p}=0.04$.

Intracellular potassium exhibited changes that were smaller in magnitude, the mean changes being -3.8 and $-3.0 \mathrm{mEq}$. during respiratory alkalosis and acidosis, respectively. Only the latter value was significant, although a significant de- crease in intracellular potassium was found during the recovery period in respiratory alkalosis.

The quantity $\Delta \mathrm{H}_{1} \sim \Delta \mathrm{Na}_{1}$ represents the sum of the transfer of hydrogen ion in one direction and transfer of sodium in the opposite direction. Since potassium transfers were small, $\Delta \mathrm{H}_{1} \sim \Delta \mathrm{Na}_{1}$ in these experiments was essentially the same as the total cation exchange. The value for this change in the case of respiratory alkalosis was $140 \mathrm{mEq}$. from the control state to the end of hyperventilation, and $123 \mathrm{mEq}$. between the end of the stimulus and the end of recovery. In the case of respiratory acidosis the changes in this quantity were 37 and $56 \mathrm{mEq}$., respectively. All four of these figures are highly significant $(p<0.001)$ and indicate that the calculated exchange of hydrogen for sodium across the phase boundary under conditions of these experiments was not a random phenomenon.

Interrelationships of cation transfers are illustrated in Figures $5 \mathrm{~A}$ and $5 \mathrm{~B}$, in which the pattern of response in each group of experiments is shown. In respiratory alkalosis (Figure $5 \mathrm{~A}$ ), the change in total extracellular bicarbonate (de- 


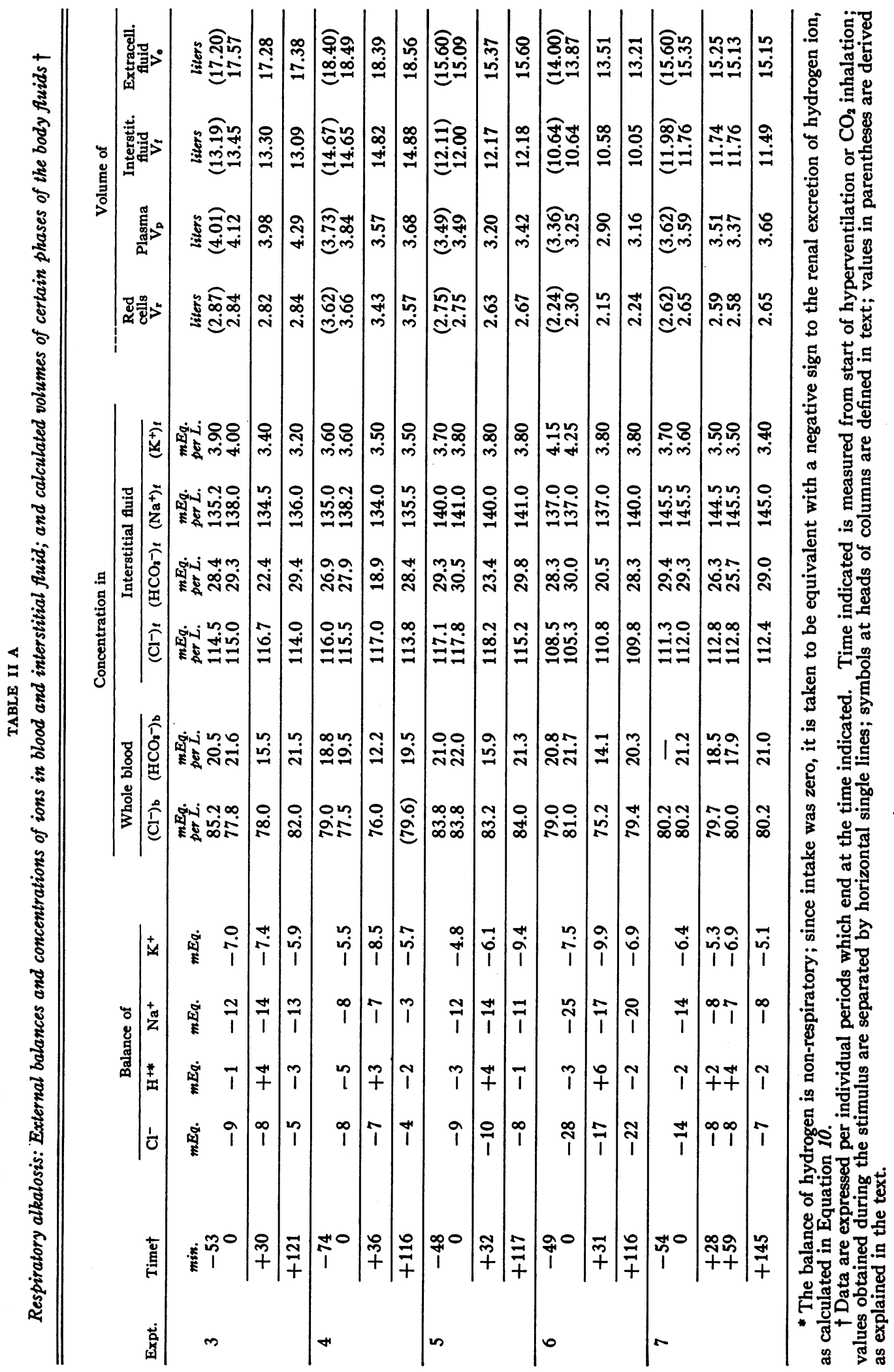




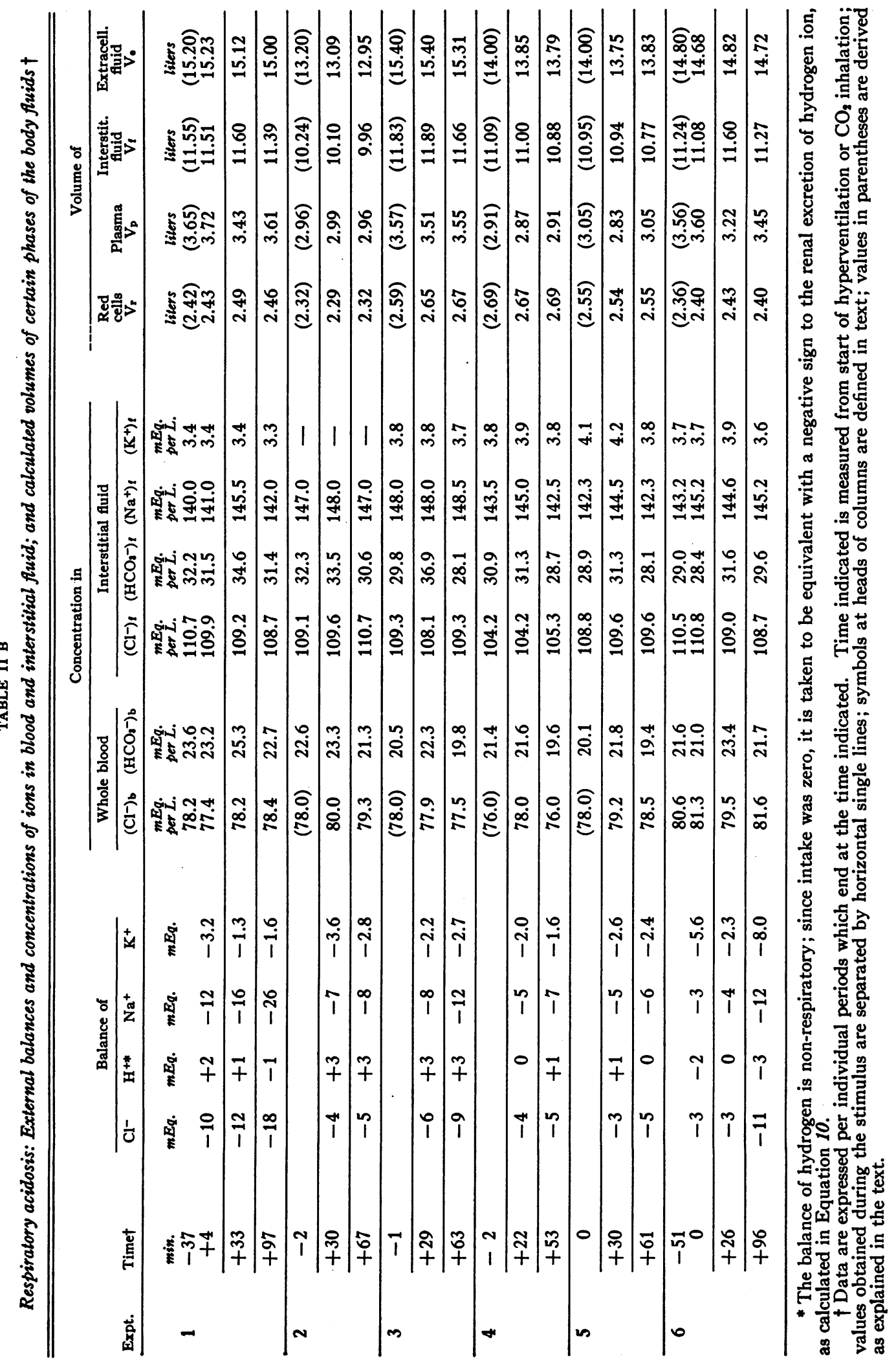




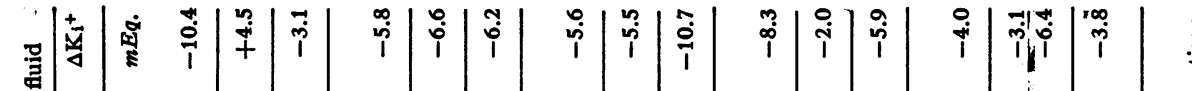

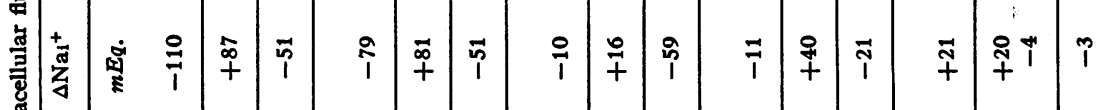

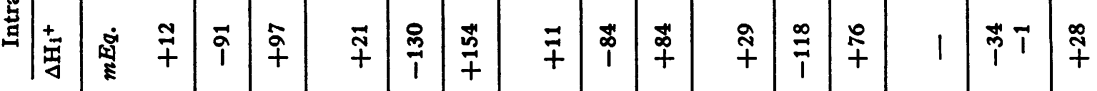

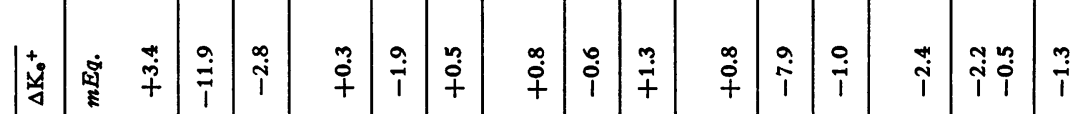

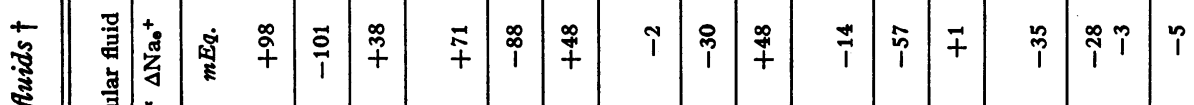

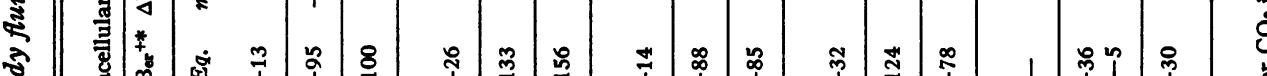

.

(5)

乌 西

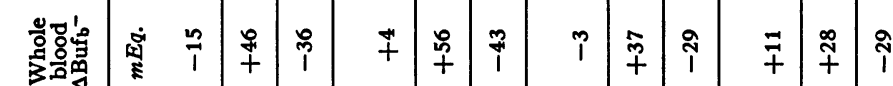

(2)

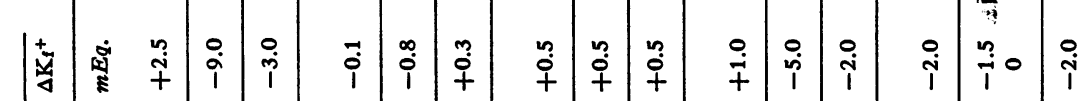

当紫

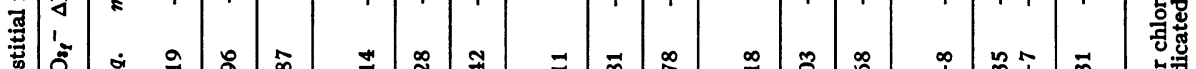

莺密

总

క⿱艹

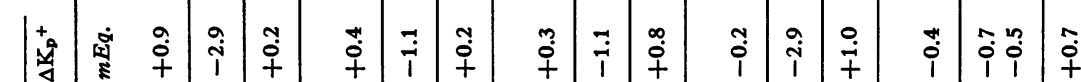

窎

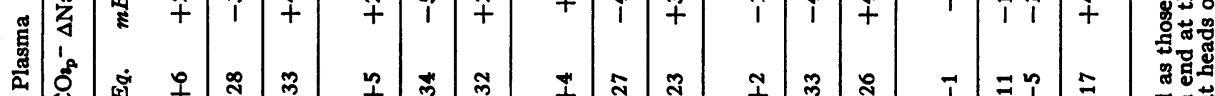

究

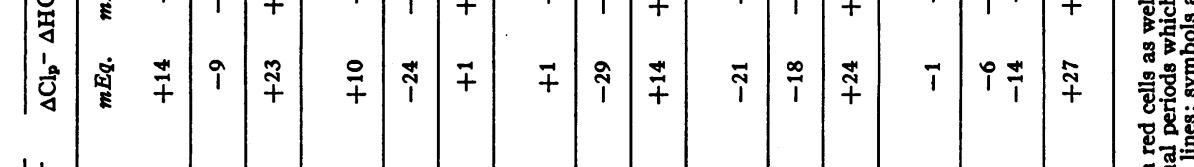

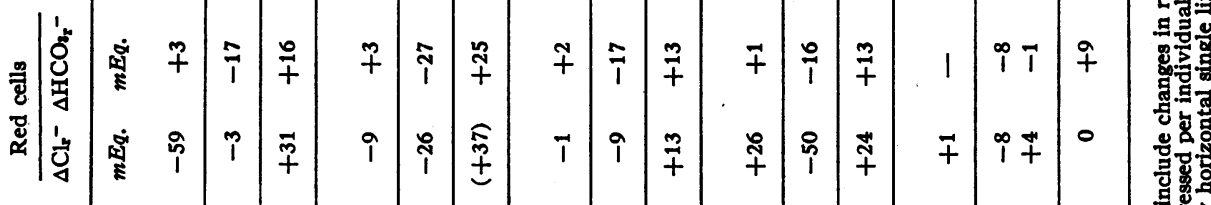

兽害管

要通

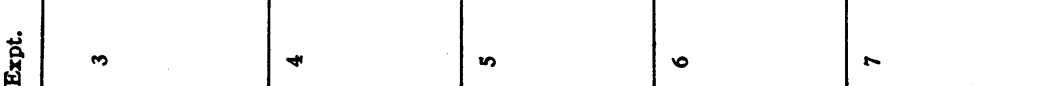


ACUTE RESPIRATORY ALKALOSIS AND ACIDOSIS IN MAN

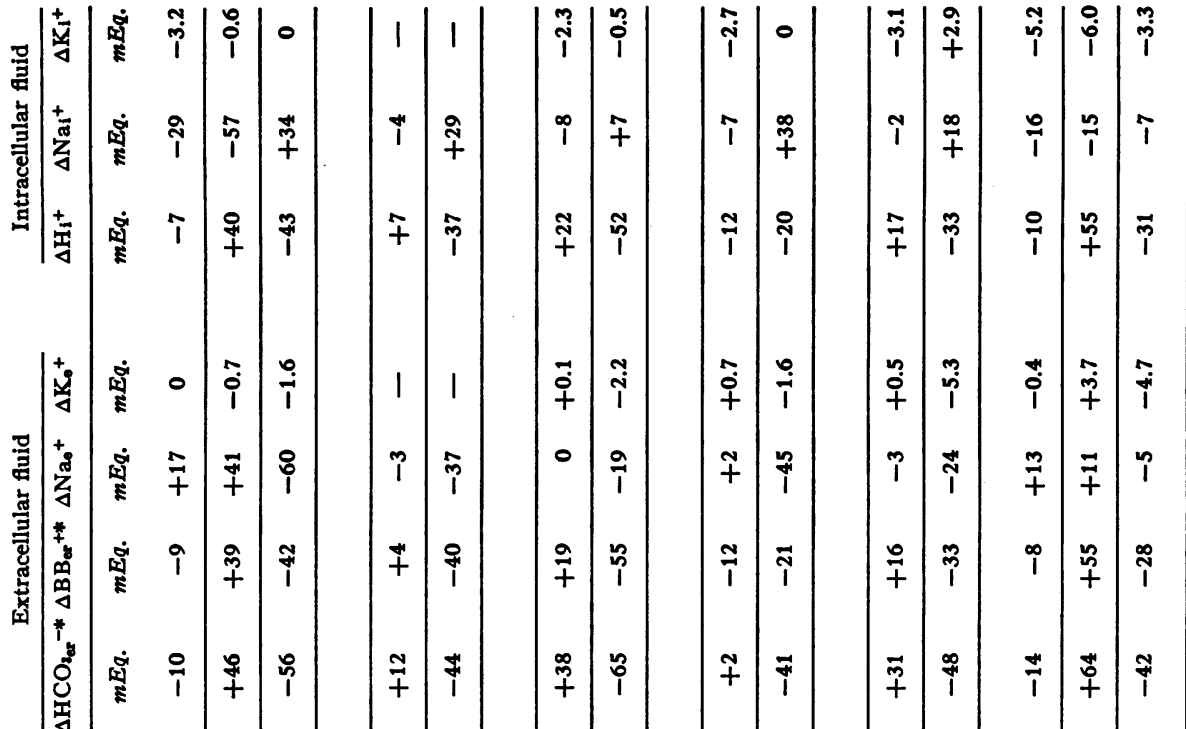

:

$\stackrel{\infty}{1} \dddot{+}$

$\stackrel{9}{i} \stackrel{\circ}{+}$

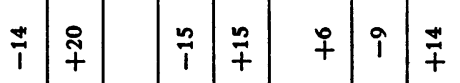

竎

|

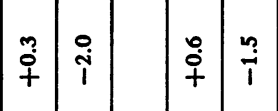

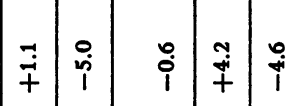

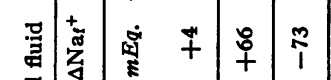

i

†ิ $\hat{i}$

m

₹

胥

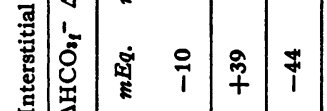

$\stackrel{\infty}{+} \underset{p}{i}$

ลิ

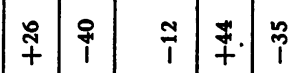

官

总苟

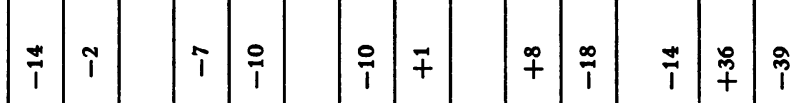

ड | 1

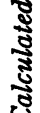

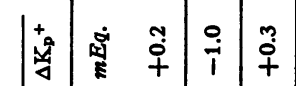

(a)

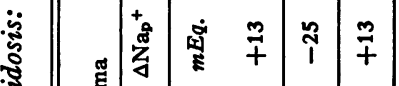

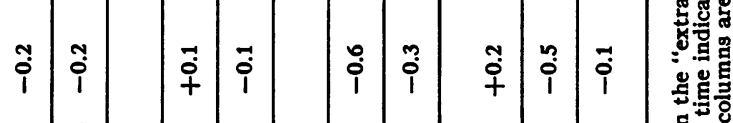

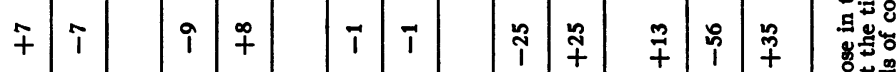

量

$¥ i$

$T i$

$\begin{array}{llllll}\hat{i} & \hat{i} & \vec{i} & \vec{i} & \vec{t}\end{array}$

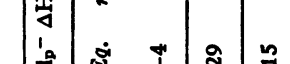

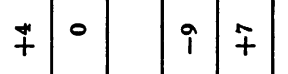

i

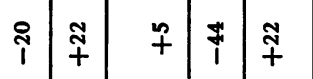

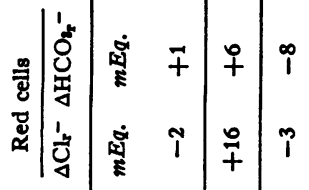

\begin{tabular}{ll}
\multirow{+}{*}{} & $i$ \\
$\stackrel{+}{+}$ & $i$
\end{tabular}

$\bar{q} i$

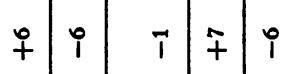

$\stackrel{m}{+}$

\begin{tabular}{lll|lll} 
& $i$ & + & $q$ & +
\end{tabular}

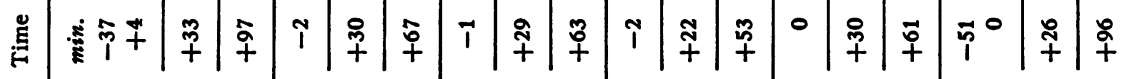
落|

₹ 
picted on the left in each figure) was mostly due to extra-renal, i.e., respiratory, loss from the body; a relatively small portion was excreted by the kidney in association with the fixed cations, potassium and sodium. On the right in each figure are shown the concomitant transfers of cations. The large respiratory losses of bicarbonate as carbonic acid required hydrogen ion which came in part from the protein buffers of the blood and in part from the body cells. The decrement of cellular hydrogen was replaced in part by an increment of cellular sodium; some portion of the remainder was associated with a transfer of undetermined anion (see below). Changes in cellular potassium were relatively insignificant.

In respiratory acidosis (Figure $5 \mathrm{~B}$ ), the opposite pattern of electrolyte transfers obtained, though to a somewhat lesser degree. The increase in total extracellular bicarbonate resulted from the $\mathrm{CO}_{2}$ inhalation rather than changes in renal excretion. The associated hydrogen ion was taken up by the protein buffer anions of the blood and by body cells. Simultaneously cellular sodium diminished while cellular potassium was essentially unchanged.

Thus our derived results indicate that acute re-
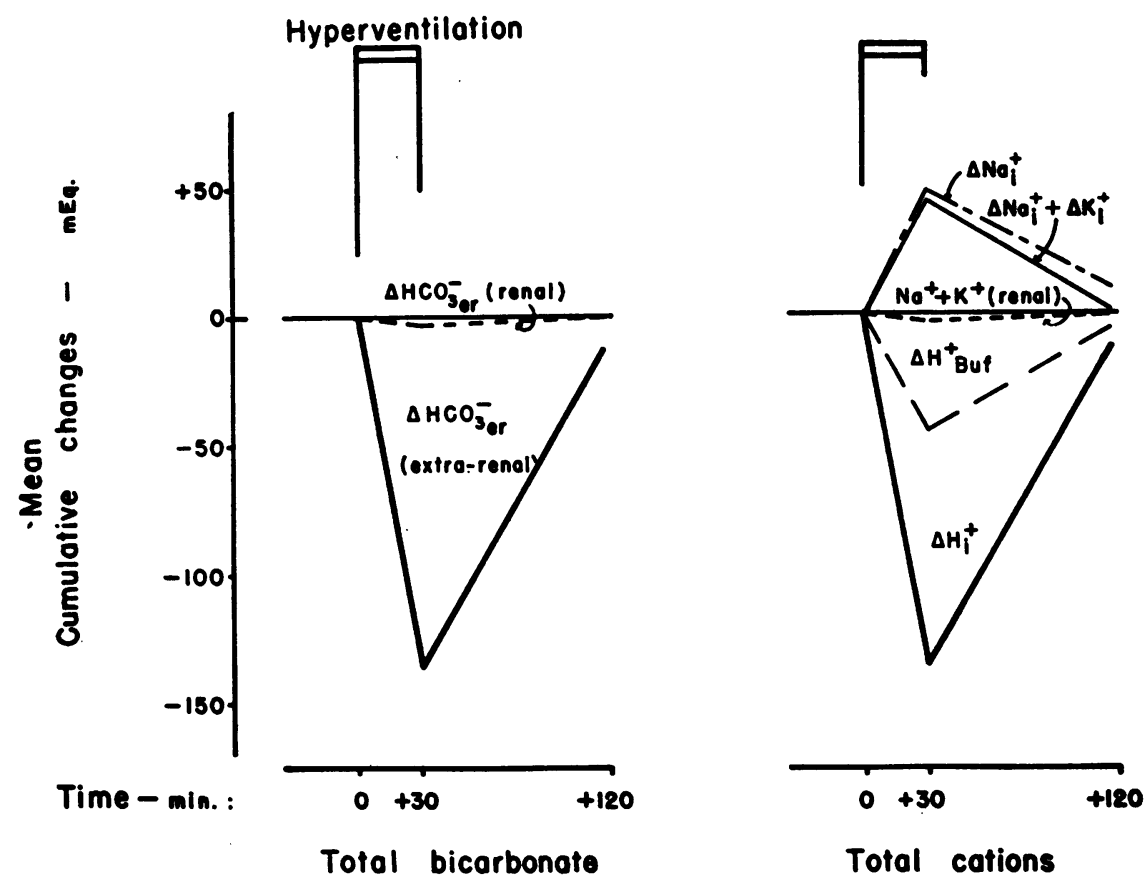

Fig. 5A. Respiratory Alkalosis: The Mean Summated Patterns of Response of Total Extracellular Bicarbonate and of Total Body Cations, to HyperVENTILATION

Changes are plotted cumulatively from the onset to the end of the stimulus and to the end of the recovery period. On the left the dotted line indicates change in bicarbonate by renal excretion; the solid line indicates the total change in extracellular bicarbonate, the difference being extra-renal or respiratory. On the right are depicted the corresponding changes in cations. The dotted line represents renal excretion of sodium and potassium, the dashed line respiratory loss of hydrogen from blood buffer proteins, and the heavy line total hydrogen loss. The difference between the two latter represents transfer of hydrogen from total body cells. The associated changes in intracellular sodium plus potassium and in intracellular sodium alone are indicated above by the solid line and dashed and dotted line, respectively.

Loss of extracellular bicarbonate by the respiratory route greatly exceeds that by the renal. Associated with the loss of bicarbonate through the lungs is the hydrogen ion drawn in part from the protein buffers of the blood and in part from body cells. The latter decrement is partially replaced by transfer of sodium into cells. 


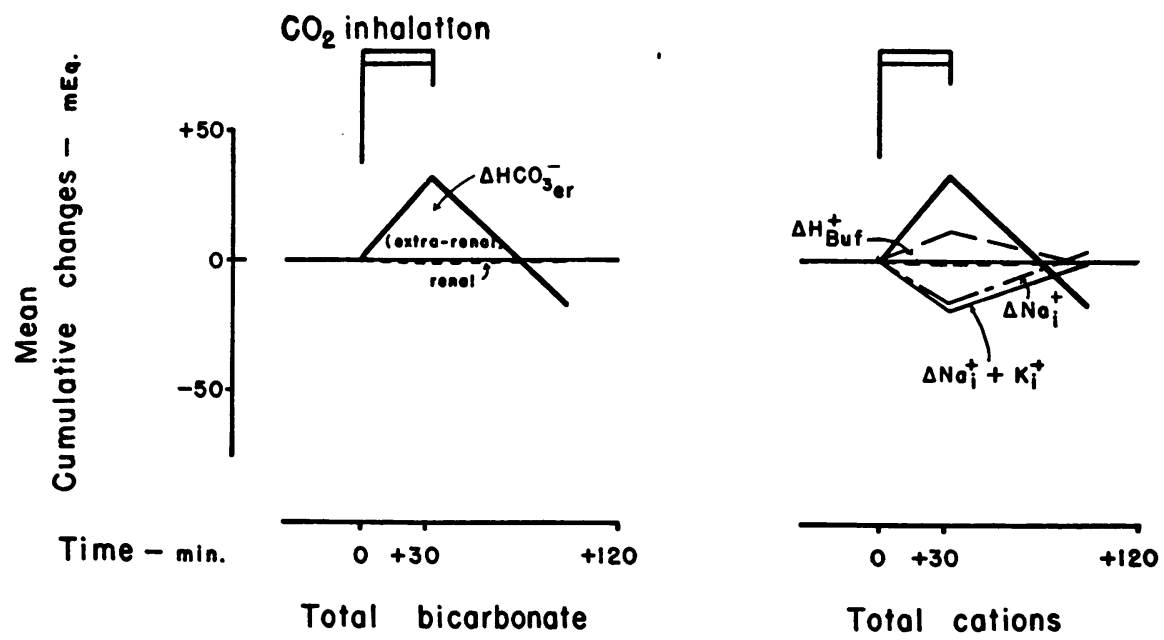

Fig. 5B. Respiratory Acidosis: The Mean Summated Patterns of Response of Total Extracellular Bicarbonate and of Total Body Cations, to $\mathrm{CO}_{2}$ InHALATION

Data are presented as in Figure 5A.

Extracellular bicarbonate is increased in respiratory retention, and hydrogen is taken up by blood protein buffers and by body cells. Simultaneously the body cells lose sodium.

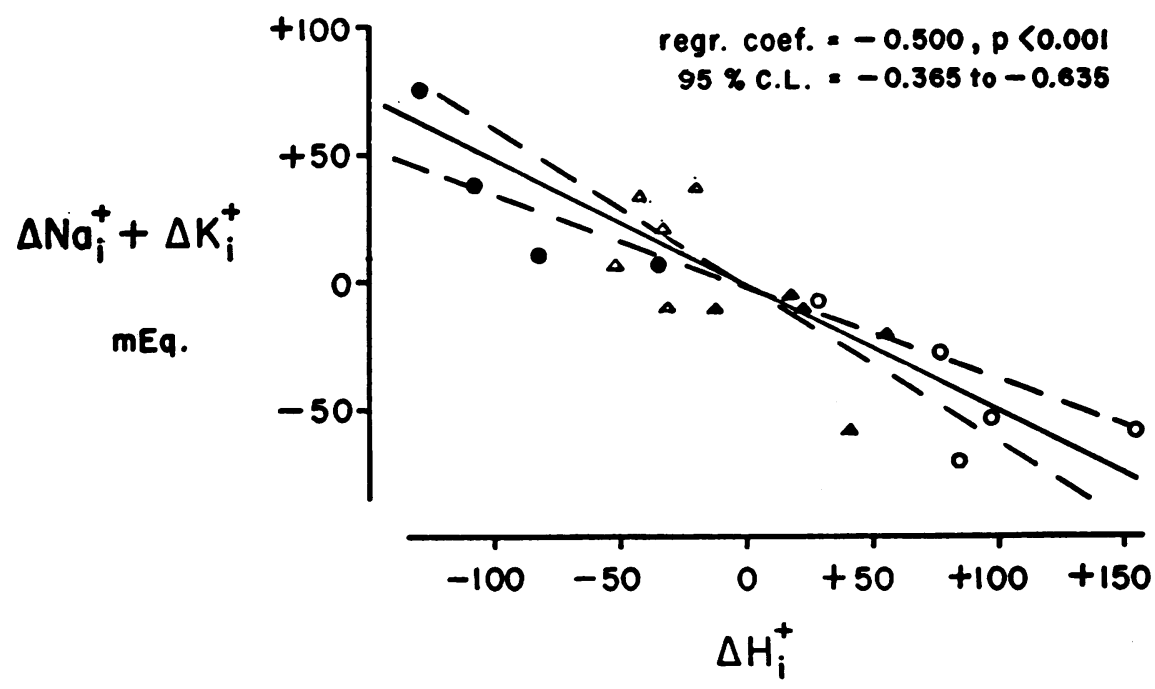

mEq.

Fig. 6. Respiratory Alkalosis and Acidosis : Relation of Calculated Transfers of Cellular Hydrogen to Those of Cellular Sodium Plus Potassium

Solid circles (representing alkalosis) and triangles (representing acidosis) indicate changes during the period of stimulus; open circles and triangles indicate changes from the end of the stimulus to the latter part of the recovery period.

The inverse correlation between the two variables indicates a reciprocal relationship between transfers of these cellular cations. The relationship, as indicated by the regression coefficient (solid line), is approximately that of two hydrogen ions in exchange for one sodium or potassium ion. 
spiratory disturbances of acid-base equilibrium involve transfers of hydrogen between the extracellular and intracellular phases of the body fluids. As shown in Figure 6, these net transfers of cellular hydrogen were reciprocally related to those of cellular sodium plus potassium; of the transfers of these two latter cellular cations, those of sodium predominated. This inverse correlation is highly significant $(\mathrm{r}=-0.868, \mathrm{p}<0.001)$. The regression coefficients for these sodium and potassium changes on the reciprocal hydrogen change were statistically significant in both sets of experiments and were not significantly different from each other. The regression coefficient for the pooled values from both groups was -0.500 with a standard error of \pm 0.0634 , thus indicating a 95 per cent chance that the true value lies between -0.365 and -0.635 . The magnitude of this relationship therefore suggests a two-for-one exchange, i.e., under these particular conditions of either acute respiratory acidosis or alkalosis approximately two hydrogen ions move for one ion of sodium and potassium considered together. Transfers of undetermined anion may explain the maintenance of electroneutrality of the extracellular fluid in the presence of this unequal exchange of cations. Calculated changes in undetermined ion approximated closely the excess of hydrogen transfer over the opposite transfer of sodium, during stimulus and recovery. Since essentially the same factors comprise both calculations, the undetermined anion data are not presented although they appear to represent a valid deduction of one link in the ionic transfers that occur in response to these respiratory acid-base stimuli.

\section{DISCUSSION}

\section{Validity of the calculations}

The principal assumption underlying the calculations is that changes in the volume of extracellular fluid may be quantitated from exchanges of chloride, i.e., the chloride space is equated with the true extracellular volume. We recognize that chloride is present in some cells and that, strictly speaking, the chloride space cannot be equated with the "true" extracellular space. However, there is an increasing body of evidence to indicate that larger molecules, such as inulin, fail to penetrate that portion of the extracellular fluid which consists of connective tissue or collagen $(32,33)$, and that this fact may well explain some of the discrepancies between the distribution of inulin and of the smaller ions, chloride, bicarbonate, and sodium $(34-36,10)$. We have discussed this problem in detail in an earlier paper (10). In the absence of a better measure of the volume of the "true" extracellular fluid, for purposes of calculation the chloride space is taken here as its approximate equivalent. It is also recognized that the movement of ions out of the chloride space does not necessarily mean that they enter cells in general or cells of any particular tissue. It is not known to what extent transcellular "pools" such as cerebrospinal fluid and gastrointestinal secretions may participate in these exchanges. Sodium has been shown to be readily mobilized from bone in certain animals $(37,38)$. But the fact that the cells of the bulk tissues, such as skeletal muscle, contain little chloride and much protein (a potential buffer), and the fact that muscle analyses by various workers have indicated changes in ionic concentration in response to acidbase disturbances, make it reasonable from the physiologic standpoint to label as "intracellular" those ions which move outside the chloride space.

Nevertheless, it is pertinent to assess the effect on our derived data of possible shifts of chloride between the true extracellular and intracellular phases of the body fluids. Those between red cells and extracellular fluid have been taken into account. If chloride did move into cells under either of our experimental conditions, the calculated increments in cellular sodium would be too small or decrements too large; conversely, if chloride had moved out of cells the reverse would be true. However, since the calculated transfers of cellular sodium and hydrogen were in opposite directions in 19 out of 22 periods of stimulus and recovery, diminution or enhancement of change in cellular sodium due to cellular chloride shift would be associated with the opposite effect on cellular hydrogen. Therefore the occurrence of such shifts of chloride, unallowed-for in the calculations, would alter the quantitative reciprocal relationship between changes in cellular sodium and hydrogen, but would not invalidate the evidence that transfers of one or both cations took place across the phase boundary.

The calculated difference between change in ex- 
tracellular buffer base and the external balance of bicarbonate is a measure of transfer of hydrogen ion in one direction in respect to cells or transfer of bicarbonate ion in the other direction. For convenience we have chosen to label the findings as movements of hydrogen ion. While it seems somewhat more probable to us that this represents the transfer involved, it is recognized that the distinction cannot be made by present methods and that the net result would be the same if instead bicarbonate ion moved in the opposite direction.

The major role of intracellular ionic transfers in buffering extracellular $p H$ changes in acid-base disturbances. The results of these experiments indicate very strongly that the cells of body tissue provide a major buffer system against the effects of acute acid-base disturbances of the respiratory type. Ninety per cent or more of the change in effective extracellular bicarbonate was extra-renal and was related to changes in hydrogen uptake or release by buffer protein in the blood and by ionic transfer into, or out of, cellular fluid in the body; only a very small fraction was accounted for by acid-base adjustments in the kidney over the short periods of time of these experiments. Exchanges of hydrogen ion with blood buffer systems and in the kidney have heretofore received much attention; exchanges of hydrogen ion with intracellular buffer systems have not been considered so extensively.

Earlier workers had demonstrated experimentally that a major portion of $\mathrm{CO}_{2}$ withdrawn from the body by hyperventilation, or retained in the body by inhalation, came from, or was added to, tissues other than blood (39-41). On the assumption of an unchanged basal R. Q., Rosenbaum (42) calculated that during hyperventilation 21 to 47 per cent of expired non-metabolic $\mathrm{CO}_{2}$ came from outside the chloride-corrected thiocyanate space ; conversely, during $\mathrm{CO}_{2}$ inhalation, 12 to 56 per cent of the $\mathrm{CO}_{2}$ was retained in this space. These studies clearly indicated that the intracellular fluid shared in the buffering of respiratory acidbase disturbances, but there was not sufficient appreciation of the obligatory nature of associated transfers of hydrogen and other cations.

These associated ionic transfers are delineated in our experiments and in the important paper by Giebisch, Berger, and Pitts (9) which has been published since our experiments were completed.
The results of their study of the extra-renal response of dogs to acute respiratory acid-base disturbances are in close agreement with our findings in man. Measured against the radio-sulfate space, transfers of chloride were found to occur only across the red cell membrane; transfers of sodium (and of potassium to a lesser degree), as well as of phosphate and lactate anions, were calculated to occur across some unkown extracellular boundary. Cellular anions are involved as well as cations. Our results, at least in respiratory alkalosis, indicate that part of the cellular buffering consisted in release of hydrogen ion with an undetermined anion. The nature of this "undetermined" anion was not identified in our experiments but it may well be lactate since an increase in extracellular lactic acid has been specifically reported to occur under these circumstances (43-45).

The relatively few analyses of tissues which are available in respiratory acid-base disturbances are in general agreement with the indirect evidence of our balance experiments. Darrow and Sarason (46) found a high muscle content of intracellular sodium in rats subjected to low oxygen tension and chronic hyperventilation. Malorny (47) found during $\mathrm{CO}_{2}$ inhalation by animals an increase of sodium and potassium, in whole muscle tissue, and a decrease in liver tissue, and suggests that these cations were exchanging with hydrogen. Cooke, Coughlin, and Segar (48) analyzed skeletal muscle from rats subjected to prolonged $\mathrm{CO}_{2}$ inhalation and partially compensated respiratory acidosis. The potassium content was at the upper limit of normal and the intracellular sodium was diminished. These results suggest an exchange of cellular sodium for hydrogen.

Acute respiratory acid-base disturbances lead to linked transfers of intracellular cations, probably as the direct result of changes in extracellular $\mathrm{pH}$; no positive or negative load of fixed cation is imposed on the body as is the case in the socalled metabolic disturbances. Intracellular exchanges of hydrogen, sodium, and potassium ions have been more widely recognized in the latter, namely, primary metabolic disturbances of acidbase equilibrium (10-14), as well as in primary deficiency of potassium (1-3, 49-51).

The relation of cellular to renal transfers. The renal and cellular adjustments of respiratory acidbase disturbances are linked reactions. The pre- 
cise patterns of these linked reactions depend upon a variety of factors, the chief of which are the intensity and duration of the primary stimulus, the time of observation, and the intrinsic adequacy of renal function. In the experiments reported here the respiratory stimuli and periods of observation were of such short duration that the renal response, although definitive in character, was of very small magnitude in relation to the calculated ionic exchanges between cells and extracellular fluid. Chronic respiratory stimuli may produce a different effect; Sullivan and Dorman (52) have demonstrated that bicarbonate reabsorption by the renal tubule is progressively enhanced in chronic, as compared to acute, respiratory acidosis. And certainly, in clinical examples of chronic respiratory acidosis, the secondary adjustment of the buffer anion concentration in extracellular fluid by the renal excretion of chloride relative to bicarbonate conditions strongly the degree of deviation of hydrogen ion concentration.

The observations reported in this paper together with those of many other investigators, as discussed above, are leading to an enlarged and more precise concept of acid-base regulation. The first and immediate defense of the neutrality of body fluids against an external agent is the physicochemical mechanism involved in the action of the buffer systems in blood. Other buffer systems called into play are, next, the bicarbonate-carbonic acid system of the rest of the extracellular fluid (including the collagen subphase), and finally, the organic phosphates and proteins of tissue cells, and some of the bone salts. In addition to the chemical action of these buffers, physiological mechanisms aid in neutrality regulation. These include regulation of respiratory minute volume so as to achieve, where possible, a higher, lower, or more normal level of $\mathrm{CO}_{2}$ pressure in body fluids; changes in cellular metabolism, such as an increase in the rate of formation of organic acids; and renal function, whereby compensatory changes in the ionic structure of plasma are effected. Although all these mechanisms are brought into play almost immediately after the acid-base disturbance is first noted in arterial blood, the full effects of respiratory compensation are achieved very rapidly, whereas those due to metabolic or renal compensation reach their maximum much later. And although all these mechanisms serve to pro- tect the relative constancy of $\mathrm{pH}$ in body fluids, the kidney is primarily responsible for the ultimate restoration of a normal ionic pattern.

\section{SUMMARY}

Ionic tranfers between the extracellular fluid (assumed to be 20 per cent of body weight with changes estimated on the basis of the chloride space) and the "intracellular" fluid were calculated in five normal subjects during and after acute respiratory alkalosis produced by hyperventilation; in another group of six subjects the same transfers were calculated during and after acute respiratory acidosis produced by $\mathrm{CO}_{2}$ inhalation. Direct calculations were made of sodium and potassium transfers as well as indirect calculations of transfers of intracellular hydrogen on the basis of changes in bicarbonate and other buffer anions in the extracellular fluid and red cells. The results were as follows:

1. In respiratory alkalosis, hydrogen left cells and sodium entered cells.

2. In respiratory acidosis hydrogen tended to enter, and sodium to leave, cells, but these mean changes were not quite significant at the 5 per cent level.

3. In both types of experiments the sums of hydrogen transfer in one direction and of sodium in the other were highly significant. The ratio of hydrogen transfer to sodium transfer in the opposite direction was approximately 2 to 1 under these conditions; a 1 to 1 transfer of anion with that of hydrogen not exchanged for sodium appeared to be involved.

4. In both types of experiments the changes in cell potassium were much smaller in magnitude or were negligible, for the short duration of the stimuli.

It is concluded that in acute respiratory acidbase disturbances a large part of the immediate buffering of the extracellular fluid is achieved by exchanges of hydrogen for sodium across the cell boundaries in body tissues.

\section{REFERENCES}

1. Darrow, D. C., The retention of electrolyte during recovery from severe dehydration due to diarrhea. J. Pediat., 1946, 28, 515.

2. Darrow, D. C., Schwartz, R., Iannucci, J. F., and Coville. $F$., The relation of serum bicarbonate con- 
centration to muscle composition. J. Clin. Invest., 1948, 27, 198.

3. Cooke, R. E., Segar, W. E., Reed, C., Etzwiler, D. D., Vita, M., Brusilow, S., and Darrow, D. C., The role of potassium in the prevention of alkalosis. Am. J. Med., 1954, 17, 180.

4. Clark, J. K., Barker, E. S., Singer, R. B., and Elkinton, J. R., The effects in man of acute experimental alkalosis and acidosis on the renal excretion of electrolytes. In preparation.

5. Singer, R. B., Clark, J. K., Barker, E. S., and Elkinton, J. R., The effects of acute respiratory alkalosis on electrolyte excretion and renal hemodynamics in man. J. Clin. Invest., 1952, 31, 663.

6. Elkinton, J. R., Singer, R. B., Barker, E. S., and Clark, J. K., Effects of acute respiratory acidosis on electrolyte excretion in man. Federation Proc., $1953,12,38$.

7. Elkinton, J. R., Singer, R. B., Clark, J. K., and Barker, E. S., The renal and cellular response to acute experimental respiratory alkalosis and acidosis. Am. J. M. Sc., 1953, 225, 579.

8. Singer, R. B., Elkinton, J. R., Barker, E. S., and Clark, J. K., Transfers of cellular cations during acute respiratory alkalosis and acidosis experimentally produced in man. J. Clin. Invest., 1953, 32, 604.

9. Giebisch, G., Berger, L., and Pitts, R. F., The extrarenal response to acute acid-base disturbances of respiratory origin. J. Clin. Invest., 1955, 34, 231.

10. Singer, R. B., Clark, J. K., Barker, E. S., Crosley, A. P., Jr., and Elkinton, J. R., The acute effects in man of rapid intravenous infusion of hypertonic sodium bicarbonate solution. I. Changes in acidbase balance and distribution of the excess buffer base. Medicine, 1955, 34, 51.

11. Schwartz, W. B., Jenson, R. L., and Relman, A. S., The disposition of acid administered to sodiumdepleted subjects: The renal response and the role of the whole body buffers. J. Clin. Invest., 1954, 33, 587.

12. Pitts, R. F., Mechanisms for stabilizing the alkaline reserves of the body. Harvey Lectures, 1952-53, 172.

13. Swan, R. C., and Pitts, R. F., Neutralization of infused acid by nephrectomized dogs. J. Clin. Invest., 1955, 34, 205.

14. Schwartz, W. B., Ørning, K. J., and Porter, R., The constant relationship between extracellular and intracellular buffering with varying degrees of metabolic acidosis. J. Clin. Invest., 1955, 34, 918.

15. Singer, R. B., and Hastings, A. B., An improved clinical method for the estimation of disturbances of the acid-base balance of human blood. Medicine, 1948, 27, 223.

16. Singer, R. B., Shohl, J., and Bluemle, D. B., A modification of the Shock and Hastings technique for the simultaneous determination of $\mathrm{pH}, \mathrm{CO}_{2}$ con- tent and cell volume in $0.1 \mathrm{ml}$. aliquots of cutaneous blood. Clinical Chemistry, 1955, 1, In press.

17. Van Slyke, D. D., and Sendroy, J., Jr., Carbon dioxide factors for the manometric blood gas apparatus. J. Biol. Chem., 1927, 73, 127.

18. Wallace, W. M., Holliday, M., Cushman, M., and Elkinton, J. R., The application of the internal standard flame photometer to the analysis of biologic material. J. Lab. \& Clin. Med., 1951, 37, 621.

19. Van Slyke, D. D., and Hiller, A., Application of Sendroy's iodometric chloride titration to proteincontaining fluids. J. Biol. Chem., 1947, 167, 107.

20. Drabkin, D. L., The standardization of hemoglobin measurement. Am. J. M. Sc., 1948, 215, 110.

21. Shock, N. W., and Hastings, A. B., Studies of the acid-base balance of the blood. I. A microtechnique for the determination of the acid-base balance of the blood. J. Biol. Chem., 1934, 104, 565.

22. Van Slyke, D. D., Weisiger, J. R., and Van Slyke, K. K., Photometric measurement of plasma $\mathrm{pH}$. J. Biol. Chem., 1949, 179, 743.

23. Dill, D. B., Edwards, H. T., and Consolazio, W. V., Blood as a physico-chemical system. XI. Man at rest. J. Biol. Chem., 1937, 118, 635.

24. Elkinton, J. R., and Winkler, A. W., Transfers of intracellular potassium in experimental dehydration. J. Clin. Invest., 1944, 23, 93.

25. Hastings, A. B., Salvesen, H. A., Sendroy, J., Jr., and Van Slyke, D. D., Studies of gas and electrolyte equilibria in the blood. IX. The distribution of electrolytes between transudates and serum. J. Gen. Physiol., 1927, 8, 701.

26. Gilligan, D. R., Volk, M. C., and Blumgart, H. L., Observations on the chemical and physical relation between blood serum and body fluids. I. The nature of edema fluids and evidence regarding the mechanism of edema formation. J. Clin. Invest., 1934, 13, 365.

27. Folk, B. P., Zierler, K. L., and Lilienthal, J. L., Jr., Distribution of potassium and sodium between serum and certain extracellular fluids in man. Am. J. Physiol., 1948, 153, 381.

28. Gibson, J. G., 2nd, and Evans, W. A., Jr., Clinical studies of the blood volume. II. The relation of plasma and total blood volume to venous pressure, blood velocity rate, physical measurements, age and sex in ninety normal humans. J. Clin. Invest., 1937, 16, 317.

29. Hopper, J., Jr., Tabor, H., and Winkler, A. W., Simultaneous measurements of the blood volume in man and dog by means of Evans Blue Dye, T1824, and by means of carbon monoxide. I. Normal subjects. J. Clin. Invest., 1944, 23, 628.

30. Stanbury, S. W., and Thomson, A. E., The renal response to respiratory alkalosis. Clin. Sc., 1952, $11,357$.

31. Scribner, B. H., and Burnell, J. M., The effect of respiratory alterations of $\mathrm{pH}$ on the internal equi- 
librium of potassium. J. Clin. Invest., 1955, 34, 919.

32. Nichols, G., Jr., Nichols, N., Weil, W. B., and Wallace, W. M., The direct measurement of the extracellular phase of tissues. J. Clin. Invest., 1953, 32, 1299.

33. Cotlove, E., Inulin and chloride space in muscle. Federation Proc., 1952, 11, 28.

34. Deane, N., and Smith, H. W., The distribution of sodium and potassium in man. J. Clin. Invest., 1952, 31, 197.

35. Deane, N., Ziff, M., and Smith, H. W., The distribution of total body chloride in man. J. Clin. Invest., 1952, 31, 200.

36. Hills, A. G., Chalmers, T. M., Webster, G. D., Jr., and Rosenthal, O., Adrenal cortical regulation of the distribution of water and electrolytes in the human body. J. Clin. Invest., 1953, 32, 1236.

37. Edelman, I. S., James, A. H., Baden, H., and Moore, F. D., Electrolyte composition of bone and the penetration of radiosodium and deuterium oxide into dog and human bone. J. Clin. Invest., 1954, 33, 122.

38. Bergstrom, W. H., and Wallace, W. M., Bone as a sodium and potassium reservoir. J. Clin. Invest., 1954, 33, 867.

39. Shaw, L. A., The comparative capacity of the blood and of the tissue to absorb carbonic acid. Am. J. Physiol., 1926, 79, 91.

40. Adolph, E. F., Nance, F. D., and Shiling, M. S., The carbon dioxide capacity of the human body and the progressive effects of carbon dioxide upon the breathing. Am. J. Physiol., 1929, 87, 532.

41. Irving, L., Ferguson, J. K. W., and Plewes, F. B., The source of $\mathrm{CO}_{2}$ expired and the site of its retention. J. Physiol., 1930, 69, 113.
42. Rosenbaum, J. D., The influence of alterations in acid-base balance upon transfers of carbon dioxide and bicarbonate in man. J. Clin. Invest., 1942, 21, 735.

43. Anrep, G. V., and Cannan, R. K., The concentration of lactic acid in the blood in experimental alkalaemia and acidaemia. J. Physiol., 1923, 58, 244.

44. Nims, L. F., Gibbs, E. L., and Lennox, W. G., Arterial and cerebral venous blood. Changes produced by altering arterial carbon dioxide. J. Biol. Chem., 1942, 145, 189.

45. Stanbury, S. W., Personal communication.

46. Darrow, D. C., and Sarason, E. L., Some effects of low atmospheric pressure on rats. J. Clin. Invest., 1944, 23, 11.

47. Malorny, G., Das Verhalten der Elektrolyte im Blut und Gewebe bei erhöhten $\mathrm{CO}_{2}$-Spannungen der Atmungsluft. Arch. f. exper. Path. u. Pharmakol., 1948, 205, 684.

48. Cooke, R. E., Coughlin, F. R., Jr., and Segar, W. E., Muscle composition in respiratory acidosis. J. Clin. Invest., 1952, 31, 1006.

49. Elkinton, J. R., Squires, R. D., and Crosley, A. P., Jr., Intracellular cation exchanges in metabolic alkalosis. J. Clin. Invest., 1951, 30, 369.

50. Cooke, R. E., Segar, W. E., Cheek, D. B., Coville, F. E., and Darrow, D. C., The extrarenal correction of alkalosis associated with potassium deficiency. J. Clin. Invest., 1952, 31, 798.

51. Gardner, L. I., MacLachlan, E. A., and Berman, H., Effect of potassium deficiency on carbon dioxide, cation, and phosphate content of muscle. With a note on the carbon dioxide content of human muscle. J. Gen. Physiol., 1952, 36, 153.

52. Sullivan, W. J., and Dorman, P. J., The renal response to chronic respiratory acidosis. J. Clin. Invest., 1955, 34, 268. 